\title{
Kemampuan Siswa dalam Memahami Bahan Ajar Sejarah Perjuangan Rakyat Bengkulu pada Aspek Kognitif dan Aspek Afektif pada Mata Pelajaran Muatan Lokal di Kelas V Sekolah Dasar Negeri 49 Kota Bengkulu
}

\author{
Titin Afrianti \\ Universitas Bengkulu \\ Titinafrianti47@gmail.com \\ Wurdjinem \\ Universitas Bengkulu \\ Wurdjinem.pgsd@yahoo.com \\ Sri Ken Kustianti \\ Universitas Bengkulu \\ Srikenkustianti17@gmail.com
}

\begin{abstract}
This study aimed to describe the ability of students to understand the teaching materials on the history of the struggle of the people of Bengkulu local content subjects at three aspects of the history of the learning outcomes of academic skills (cognitive), awareness of history (affective), nationalism (affective). This type of research is descriptive quantitative research with descriptive methods and techniques percentage. The subjects were students of class VA amounting to 23 students. The research instrument used is a matter of objective test sheet form and the sheet observation / observasi.teknik data analysis by scoring on a multiple choice test and scoring on a sheet of observation / observation later described. From the research that VA grade students of State Elementary School 49 Bengkulu City was able to understand the history of the struggle of people teaching materials Bengkulu with an average of $68.11 \%$ in understanding the teaching materials on the history of the struggle of the people of Bengkulu local content subjects. However, if viewed from the completeness graders said VA has not been completed, because based on the assessment of students declared complete benchmark reference when getting values over 65 as much as $75-80 \%$. It can be concluded that based on the calculation that has been obtained in the aspect of academic skills (cognitive) as many as 12 students (52.17\%) were able to
\end{abstract}




\begin{abstract}
understand the history of the struggle of the people teaching materials Bengkulu, A total of 16 students (69.56\%) had a history conscious attitude. And to nationalism as many as 19 students (82.60\%) were able to have an attitude of nationalism.

\section{Keywords: Subjects, History of People's Struggle Bengkulu, Local Content, Learning Outcomes}

\title{
Pendahuluan
}

Pada saat ini sejarah nasional bangsa Indonesia sedang hangat di perbincangkan dalam dunia pendidikan. Hal ini sebabkan karena sejarah nasional mengandung informasi dan sumber yang lengkap sebagai bahan ajar untuk meningkatkan kemampuan siswa dalam belajar. Namun sejarah nasional pada saat ini mengalami masalah seperti sejarah nasional kerap mengabaikan makna tentang sejarah lokal, kurang diketahuinya bagianbagian sejarah nasional secara utuh dan kurangya perhatian pemerintah akan pentingnya sejarah nasional untuk dikembangkan secara menyeluruh. Kurangnya pengetahuan tentang sejarah nasional juga berdampak pada sejarah lokal yang dimiliki oleh masyarakat setempat. Padahal sejarah lokal yang dimiliki oleh masyarakat setempat mempunyai proporsi yang strategis dalam memperkaya sumber informasi khususnya dalam pembelajaran. pelajaran sejarah dianggap membosankan oleh peserta didik karena pelPelajaran sejarah di sekolah faktanya sebagai rangkaian fakta-fakta yang berupa urutan tahun, tokoh dan peristiwa belaka yang jauh dari lingkungan sosial peserta didik, terutama diluar jawa, karena selama ini materi kurikulum di dominasi peristiwa di pulau jawa, sementara peristiwa dan peran tokoh di daerah lain yang tidak sedikit dan tidak kalah pentingnya termasuk di daerah Bengkulu yang tidak pernah diajarkan. Materi pembelajaran sejarah yang diberikan kepada siswa SD hingga SMA hampir tidak jauh berbeda materi pembelajaran mengenai proklamasi kemerdekaan RI, Perang Diponegoro, Pattimura serta Pangeran Antasari. yang terusmenerus diajarkan sehingga membuat siswa berpikir bahwa pelajaran sejarah membosankan.

Menurut Wahyudhi dan Madjid (2014: 3), pelajaran sejarah dianggap sebagai sesuatu yang membosankan, oleh karena terjebak dalam tradisi menghafal nama-nama tokoh dan tahun kejadiannya. Pelajaran sejarah yang diajarkan sejak sekolah dasar hingga sekolah lanjutan tidak mampu menghadirkan esensi dari setiap peristiwa.Sejalan dengan pendapat di atas Aman (2011: 7) mengemukakan, "pembelajaran sejarah di sekolah kurang diminati oleh peserta didik dan dianggap sebagai pelajaran yang membosankan karena seolah-olah cenderung hapalan, sehingga banyak peserta didik menganggap bahwa pelajaran sejarah tidak membawa manfaat karena kajiannya masa lampauajaran sejarah mempelajari sejarah yang jauh dari lingkungan sosial peserta didik.

Masalah selanjutnya yang menjadi keresahan saat ini ialah peserta didik belum mengenal sejarah yang ada pada lingkungan mereka berada. Hal ini yang menyebabkan kurangnya kesadaran kebangsaan yang dimiliki peserta didik. Nilai-nilai kepahlawanan, nilai nasionalisme, patriotisme juga nilai 
kearifan lokal sendiri kurang dipahami. Peserta didik tidak memahami sejarah yang ada pada daerah mereka sendiri, hal ini disebabkan peserta didik lebih banyak belajar tentang sejarah nasional dan guru-guru sejarah lebih banyak bukan dari jurusan sejarah mengakibatkan pemahaman siswa terhadap peristiwa masa lampau menjadi rendah. Hal tersebutlah yang membuat peserta didik tidak memiliki rasa ingin tahu terhadap sejarah yang ada di daerahnya.

Hal yang menyebabkan peserta didik di Sekolah Dasar tidak memahami sejarah lokal karena terbatasnya bahan atau sumber buku yang mengarahkan pada sejarah lokal. Pada umumnya, sumber belajar (bahan ajar) yang ada di Sekolah Dasar memang di terbitkan dari daerah lain. Ini terjadi, karena kurangnya rasa peduli pemerintah daerah untuk mengembangkan bahan ajar yang memang berorientasi pada kearifan lokal. Kurangnya, kreatifitas guru untuk mencari dan menambah sumber belajar (bahan ajar) termasuk salah satunya sumber belajar (bahan ajar) kearifan lokal khususnya di Bengkulu. Pada dasarnya guru dan peserta didik masih kurang memiliki rasa peduli terhadap kearifan lokal mereka sendiri.

Untuk mengatasi permasalahan tentang bagaimana kearifan lokal dapat diajarkan kepada peserta didik agar mereka memiliki rasa kepedulian dan rasa nasionalisme terhadap sejarah lokal maka dibuatlah kurikulum muatan lokal seperti yang dikemukakan Mulyasa (2010: 271-272), "dimasukkannya muatan lokal dalam kurikulum pada dasarnya dilandasi oleh kenyataan bahwa Indonesia memiliki beranekaragam adat istiadat, kesenian, tata cara, tata krama pergaulan, bahasa, dan pola kehidupan yang diwariskan secara turun temurun dari nenek moyang Indonesia serta sejarah yang ada di berbagai daerah.

Mempelajari sejarah sebaiknya dilakukan dari usia dini sekolah dasar. Oleh karena dengan mempelajari sejarah selain menambah pengetahuan peserta didik hal ini juga sebagai salah satu cara untuk menanamkan sikap cinta tanah air dan juga mencari jati diri bangsa khususnya bagi peserta didik di daerah Bengkulu.

Berdasarkan hasil pengamatan yang dilakukan selama melakukan pra penelitian di Sekolah Dasar Negeri 49 Kota Bengkulu, terdapat beberapa permasalahan yang ditemukan, yaitu: (1) Sekolah Dasar Negeri 49 Kota Bengkulu belum memaksimalkan penggunaan bahan ajar untuk muatan lokal yang mengarahkan kepada kebudayaan daerah setempat; (2) dalam pembelajaran muatan lokal siswa hanya menggambar dan membatik padahal pembelajaran muatan lokal seharusnya mengali potensi yang ada didaerah yang dapat dijadikan sumber informasi bagi; (3) peserta didik masih banyak tidak mengetahui sejarah lokal karena keterbatasan sumber bahan ajar.

Dari hasil observasi yang telah dilakukan dapat dijelaskan bahwa Sekolah Dasar Negeri 49 kota Bengkulu belum menerapkan muatan lokal yang berbasis pada kearifan lokal. Sekolah Dasar 49 kota Bengkulu masih kekurangan sumber belajar (bahan ajar) yang mengarahkan pada kearifan lokal, sehingga peserta didik kurang memiliki rasa peduli terhadap kearifan 
lokal Bengkulu. Sebagai contoh peserta didik di Sekolah Dasar Negeri 49 Kota Bengkulu belum begitu memahami sejarah perjuangan rakyat bengkulu pada saat melawan para penjajah dari bangsa Inggris, Belanda dan Jepang. padahal sudah dibuktikan dengan adanya peninggalan bersejarah yang ada di kota Bengkulu. Hal ini disebabkan siswa hanya belajar tentang sejarah nasional sedangkan sejarah lokal tidak dipelajari

\section{Metode}

Jenis penelitian yang digunakan dalam penelitian ini adalah penelitian deskriptif kuantitatif metode deskriptif dengan teknik persentase. Bentuk analisisnya dipaparkan secara kuantitatif dan kualitatif

\section{Populasi dan Sampel}

Menurut Sugiyono (2014: 80), populasi adalah wilayah generalisasi yang terdiri dari objek/subyek yang mempunyai kualitas dan karateristik tertentu yang ditetapkan oleh peneliti untuk dipelajari dan kemudian ditarik kesimpulannya. Populasi dalam penelitian ini berjumlah 45 siswa yang tediri dari dua kelas VA 22 orang dan VB terdiri dari 23 orang siswa di SDN 49 kota Bengkulu.

\section{Sampel Penelitian}

Menurut Sugiyono (2014: 81), sampel adalah bagian dari jumlah dan karateristik yang dimiliki oleh populasi tersebut. Sejalan dengan pendapat di atas Menurut Arikunto (2010: 95) "dalam pengambilan sampel, apabila subyek penelitian kurang dari 100 lebih baik diambil semua subyeknya sehingga disebut penelitian populasi, namun apabila subyek penelitian lebih dari 100 maka dapat diambil $10 \%, 20 \%$ atau dengan menggunakan perhitungan tertentu".

Sampel dalam penelitian ini adalah keseluruhan dari populasi karena subyek penelitian berjumlah kurang dari 100 orang siswa. Penentuan kelas eksperimen menggunakan teknik Random Sampling. Menurut Arikunto (2010: 95), Sampling Acak (Random Sampling) digunakan apabila darimana sampel diambil merupakan populasi homogen yang hanya mengandung satu ciri. Dengan demikian sampel yang dikehendaki dapat diambil secara sembarang (acak) saja.

Teknik Random Sampling dibagi lagi menjadi beberapa teknik. Pada penelitian ini pengambilan sampel dilakukan menggunakan teknik Cluster Random Sampling, yaitu teknik yang digunakan apabila di dalam populasi terdapat kelompok-kelompok individu atau cluster yang mempunyai cirri sendiri-sendiri (Arikunto, 2010: 96). Setelah melakukan uji homogenitas ternyata kelas VA dan kelas VB merupakan kelas yang homogen, sehingga peneliti langsung mengacak kelas VA dan VB untuk diambil 1 kelas saja. Dari hasil pengundian didapatkan kelas VA yang akan dilakukan penelitian Dari data hasil ujian bulanan siswa di kelas VA diatas maka diketahui Fhitung $<$ Ftabel maka data dinyatakan homogen, dari hasil pengundian didapatkan kelas VA yang berjumlah 23 orang siswa sebagai sebagai kelas eksperimen. 
Dalam penelitian ini, teknik yang digunakan peneliti untuk mengumpulkan data adalah lembar tes pilihan ganda (postest) dan lembar pengamatan/observasi. Untuk lembar tes

1) Pengolahan dan analisis data dalam penelitian ini Melihat hasil test siswa berupa soal obyektif bentuk pilihan ganda (multiple choice item test)

2) Memberikan pembobotan skor dalam tes pilihan ganda dengan rumus correction for guessing yaitu sebagai berikut:

Rumus:

$$
\begin{array}{ll|}
\cline { 2 - 3 } & \mathrm{S}=\Sigma R \frac{\Sigma W}{n-1} \\
& \quad \begin{array}{l}
\text { Keterangan: } \\
\text { = skor yang dicari }
\end{array} \\
\mathrm{S} & =\text { jumlah soal yang dijawab benar } \\
\Sigma \mathrm{W} & =\text { jumlah soal yang dijawab salah } \\
\mathrm{n} & =\text { jumlah option (alternatif jawaban tiap soal) } \\
1 & =\text { bilangan tetap }
\end{array}
$$

Sebagai contoh seorang siswa menjawab betul 20 soal pilihan ganda dari 20 soal yang tersedia. Soal bentuk pilihan ganda dengan menggunakan option sebanyak 4 buah (a,b,c,d). Maka penyelesaiannya adalah sebagai berikut ini.

$$
\text { Skor }=20-\frac{0}{4-1}=20
$$

Jadi, skor yang diperoleh siswa tersebut adalah 20

3) Kemudian pembobotan skor tersebut dimasukkan kedalam acuan penilaian khusus untuk soal obyektif pilihan ganda dengan rumus sebagai berikut:

Rumus :

$$
\mathrm{NP}=\frac{R}{S M} \times 100
$$

Keterangan:

$\mathrm{NP} \quad=$ nilai yang di cari

$\mathrm{R} \quad=$ skor mentah yang diperoleh siswa

$\mathrm{SM}=$ skor maksimum ideal dari tes yang bersangkutan

$100=$ bilangan tetap

Sebagai contoh sebelumnya siswa mendapatkan skor mentah 20 kemudian skor tersebut dimasukkan dalam penilaian sebagai berikut:

$\mathrm{NP}=\frac{20}{20} x 100=100$

Jadi, nilai yang diperoleh siswa tersebut adalah 100 .

4) Selanjutnya nilai tersebut didasarkan atas sistem persentase $0-100 \%$

Dari tabel tersebut, dapat dijelaskan bahwa siswa yang mendapatkan kategori mampu apabila mendapatkan nilai A dengan interval tingkat penguasaannya 80-100 dan mendapatkan nilai B dengan interval tingkat penguasaannya 65-79. Siswa dikatakan mampu memahami bahan ajar sejarah perjuangan rakyat Bengkulu apabila mendapatkan skor A dan B.

5) Merekapitulasi siswa yang mampu dan tidak mampu memahami bahan ajar sejarah perjuangan rakyat bengkulu berdasarkan aspek kecakapan akademik (kognitif). 
6) Mendeskripsikan kemampuan siswa dalam memahami bahan ajar lokal sejarah perjuangan rakyat Bengkulu pada mata pelajaran muatan lokal berdasarkan kecakapan akademik (kognitif).

Selanjutnya untuk melihat sikap kesadaran sejarah dan sikap nasionalisme maka digunakan lembar pengamatan/observasi yang menggunakan skala penilaian (rating scale). skala penilaian adalah pencatatan objek atau gejala penelitian menurut tingkat-tingkatnya. Skala penilaian pada penelitian ini adalah bentuk kuantitas yang menggunakan rating scale dalam bentuk klasifikasi.

Sebagai contoh lembar pengamatan/observasi sikap kesadaran sejarah, yang indikatornya ada 3 dan sub indikatornya ada 7. Jika semua sub indikator siswa mendapatkan skor 4 yang diperoleh dari deskriptor $(1,2,3,4)$ maka skor siswa $=$ bobot nilai $\mathrm{x}$ sub indikator $=4 \mathrm{x} 7=28$.

Menurut Widoyoko (2011: 259) mengklasifikasikan kriteria kemampuan memahami siswa menjadi lima kategori, yakni sangat baik, baik, cukup dan kurang sekali. Berikuti ini tabel kriteria penghitungan untuk sikap kesadaran sejarah.

Berdasarkan penentuan kriteria perhitungan di atas, siswa dikatakan mampu memiliki sikap kesadaran sejarah apabila mendapatkan skor A dengan rentang skor 24-28 (sangat baik) dan mendapatkan skor B dengan rentang skor 18-23 (baik).Kemudian untuk sikap nasionalisme digunakan lembar pengamatan/ observasi yang menggunakan skala penilaian (rating scale). Skala penilaian adalah pencatatan objek atau gejala penelitian menurut tingkat-tingkatnya. Skala penilaian pada penelitian ini adalah bentuk kuantitas yang menggunakan rating scale dalam bentuk klasifikasi. Sebagai contoh lembar pengamatan/observasisikap nasionalisme, yang indikatornya ada 7 dan sub indikatornya ada 14, jika semua sub indikator siswa mendapatkan skor 4 yang diperoleh dari deskriptor $(1,2,3,4)$ maka skor siswa $=$ bobot nilai $\mathrm{x}$ sub indikator $=4 \times 14=56$. Selanjutnya skor tersebut diklasifikasikan berdasarkan kriteria rentang skor.

Berdasarkan penentuan kriteria perhitungan siswa dikatakan memiliki sikap nasionalisme apabila mendapatkan skor A dengan rentang skor 46-56 (sangat baik) dan mendapatkan skor B dengan rentang skor 36-45 (baik).

\section{Hasil Dan Pembahasan}

Hasil penelitian ini membahas tentang kemampuan siswa dalam memahami bahan ajar sejarah perjuangan rakyat Bengkulu pada mata pelajaran muatan lokal di Sekolah Dasar Negeri 49 Kota Bengkulu yang dilihat berdasarkan 3 aspek yaitu aspek kecakapan akademik (kognitif), sikap kesadaran sejarah (afektif) dan sikap nasionalisme (afektif). Berdasarkan hasil penelitian yang telah dilakukan selama proses pembelajaran berlangsung secara umum siswa Sekolah Dasar Negeri 49 Kota Bengkulu cukup mampu dengan rata-rata $68,11 \%$ dalam memahami bahan ajar sejarah perjuangan rakyat Bengkulu. 
Hal ini dilihat dari hasil aspek kecakapan akademik siswa kelas VA SDN 49 Kota Bengkulu hanya terdapat 12 orang siswa (52,17\%) yang mampu memahami bahan ajar sejarah perjuangan rakyat Bengkulu dilihat dari tes soal objektif yang diberikan setelah melaksanakan pembelajaran. Pada sikap kesadaran sejarah terdapat 16 orang siswa $(69,56 \%)$ yang mampu memiliki sikap kesadaran sejarah dan 19 orang siswa $(82,60 \%)$ mampu memiliki sikap nasionalisme.

Jika dilihat dari hasil yang telah didapatkan yaitu rata-rata $68,11 \%$, maka secara umum siswa kelas VA belum tuntas dalam memahami bahan ajar muatan lokal. Berdasarkan penilaian acuan patokan (PAP) siswa dikatakan tuntas memahami bahan ajar jika siswa berhasil menguasai atau mencapai $\geq 75-80 \%$ ketuntasan. Sedangkan hasil penelitian yang telah didapatkan $<75 \%$ siswa mampu menguasai bahan ajar sehingga dapat dikategorikan bahwa siswa Sekolah Dasar Negeri 49 Kota Bengkulu belum tuntas memahami bahan ajar sejarah perjuangan rakyat Bengkulu. Berikut hasil deskripsi kemampuan siswa berdasarkan kecakapan akademik (kognitif):

Berdasarkan hasil rekapitulasi analisis deskriptif terhadap kemampuan siswa dalam memahami bahan ajar sejarah perjuangan rakyat Bengkulu pada mata pelajaran muatan lokal di atas, terdapat 4 siswa (17,39\%) mendapatkan nilai dengan kategori sangat baik pada interval tingkat penguasaan yaitu $80-100$, kemudian terdapat 8 siswa $(34,78 \%)$ mendapatkan nilai dengan kategori baik pada interval tingkat penguasaan 65-79, selanjutnya terdapat 4 siswa $(17,39 \%)$ mendapatkan nilai dengan kategori cukup pada interval tingkat penguasaan yaitu 55-64, selanjutnya terdapat 5 siswa (21,73\%) mendapatkan nilai dengan kategori cukup pada interval tingkat penguasaan yaitu 40-55, dan yang terakhir terdapat 2 siswa $(8,71 \%)$ mendapatkan nilai dengan kategori gagal pada interval 30-39. Dari hasil rekapitulasi di atas, peneliti melihat bahwa masih terdapat siswa yang kesulitan untuk memperoleh hasil yang baik dalam memahami bahan ajar sejarah perjuangan rakyat Bengkulu pada mata pelajaran muatan lokal.

Seperti yang dikemukakan oleh Belawati (2006: 1,7) bahan ajar yag penuh gambar dan dibuat berwana dapat meningkatkan semangat dan motivasi belajar siswa, karena bahan ajar dengan tampilan yang menarik dapat menarik siswa untuk mempelajarinya.

Penggunaan bahan ajar dapat membantu siswa untuk belajar dengan lebih cepat. Prastowo (2013: 300) menjelaskan bahwa dengan menggunakan bahan ajar, siswa dapat belajar dengan kecepatannya masing-masing, hal ini dapat dilihat dari hasil belajar siswa yang memiliki tingkat kemampuan yang berbeda-beda

Deskripsi Kemampuan Siswa Dalam Memahami Bahan Ajar Sejarah perjuangan rakyat Bengkulu pada Aspek Kesadaran Sejarah (Afektif). Pada aspek sikap kesadaran sejarah peneliti melakukan observasi dengan menggunakan lembar pengamatan. Pada sikap kesadaran sejarah terdapat 3 indikator yang kemudian dibuat sub indikator sebanyak 7 sub indikator. Berikut ini hasil deskriptif sikap kesadaran sejarah yang telah diamati peneliti selama melakukan penelitian pada saat proses pembelajaran. 
Berdasarkan hasil pengamatan yang dilakukan penelitidapat dijelaskan bahwa siswa kelas V Sekolah Dasar Negeri 49 Kota Bengkulu yang memiliki sikap kesadaran sejarah hanya terlihat tiga orang siswa pada rentang skor 24-28 kategori skor A dengan persentase sebesar 13,04\%, tigabelas orang siswa pada rentang skor 18-23 kategori skor B dengan persentase sebesar $56,65 \%$, enam orang siswa pada rentang skor 13-17 kategori skor C dengan persentase $26,08 \%$ serta satu orang siswa pada rentang skor 7-12 kategori skor D dengan persentase 4,34\%. Hasil lembar pengamatan ini dilihat dari 3 indikator pada sikap kesadaran sejarah yaitu: (1) menghayati makna dan hakikat sejarah bagi masa kini dan masa yang akan datang; (2) mengenal diri sendiri dan bangsanya; (3) membudayakan sejarah bagi pembinaan budaya bangsa.

Menurut Aman (2011: 33) kesadaran sejarah merupakan kondisi kejiwaan yang menunjukkan tingkat penghayatan pada makna dan hakekat sejarah bagi masa kini dan masa yang akan datang, mampu mengenal diri sendiri dan bangsa, membudayakan sejarah untuk pembinaan budaya bangsa dan menyadari dasar pokok bagi berfungsinya makna sejarah dalam proses pendidikan.

Berdasarkan hasil pengamatan yang dilakukan peneliti dapat dijelaskan bahwa siswa kelas V Sekolah Dasar Negeri 49 Kota Bengkulu yang mampu memiliki sikap nasionalisme hanya terlihat lima orang siswa pada rentang skor 46-56 kategori skor A dengan persentase sebesar 21,73\%, empat belasorang siswa pada rentang skor 36-45 kategori skor B dengan persentase sebesar 60,86\%, empat orang siswa pada rentang skor 25-35 kategori skor C dengan persentase $17,39 \%$ Hasil lembar pengamatan ini dilihat dari 7 indikator pada sikap nasionalisme yaitu: (1) perasaan bangga sebagai bangsa Indonesia; (2) rasa cinta tanah air dan bangsa; (3) rela bekorban demi bangsa; (4) menerima kemajemukan; (5) bangga pada budaya yang beranekaragam; (6) menghargai jasa para pahlawan; (7) mengutamakan kepentingan umum.

Dalam penelitian ini kemampuan siswa dalam memahami bahan ajar muatan lokal sejarah perjuangan rakyat Bengkulu di Kelas V Sekolah Dasar Negeri 49 Kota Bengkulu dilihat dari 3 aspek yaitu kecakapan akademik (kognitif), sikap kesadaran sejarah (afektif) dan sikap nasionalisme (afektif). Berdasarkan hasil penelitian siswa SDN 49 Kota Bengkulu cukup mampu dalam memahami bahan ajar muatan lokal sejarah perjuangan rakyat Bengkulu dilihat dari aspek kecakapan akademik, sikap kesadaran sejarah dan sikap nasionalisme.

Berdasarkan hasil yang telah diperoleh tersebut dikatakan belum tuntas karena belum menacapai $75 \%$. Hal ini sesuai dengan pendapat Sudjana (2011: 8) yang menyatakan, berdasarkan penilaian acuan patokan siswa dinyatakan menguasai semua materi jika mendapatkan ketuntasan rata-rata 75-80\%. Sehingga siswa dinyatakan tuntas jika mendapatkan nilai 65 ke atas sebanyak 75\%. Sedangkan siswa kelas V SDN 49 Kota Bengkulu yang mendapatkan nilai 65 ke atas sebanyak 68,11\%. Hasil tersebut diperoleh dari rata-rata pada aspek kecakapan akademik (kognitif) sebanyak 12 orang 
siswa (52,17\%), pada aspek sikap kesadaran sejarah (afektif) sebanyak 16 orang siswa $(69,56 \%)$ dan pada sikap nasionalisme (afektif) sebanyak 19 orang siswa (82,60\%). sehingga dapat disimpulkan bahwa siswa kelas V SDN 49 Kota Bengkulu belum tuntas dalam memahami bahan ajar sejarah perjuangan rakyat Bengkulu pada mata pelajaran muatan lokal.

Berdasarkan data yang diperoleh dari hasil penelitian menunjukkan 16 orang siswa $(69,56 \%)$ yang sudah mampu memiliki sikap kesadaran sejarah, sedangkan siswa yang tidak mampu memiliki sikap kesadaran sejarah diperoleh sebanyak 7 orang siswa $(30,43 \%)$.

Berdasarkan data yang diperoleh dari hasil penelitian menunjukkan 19 orang siswa $(82,60 \%)$ yang sudah mampu memiliki sikap nasionalisme, sedangkan siswa yang tidak mampu memiliki sikap nasionalisme diperoleh sebanyak 4 orang siswa (17,39\%).

Menurut Faturrohman (2013:110) sikap nasionalisme adalah cara berpikir, bersikap, dan berbuat yang menunjukkan kesetiaan, kepedulian, dan penghargaan yang tinggi terhadap bahasa, lingkungan fisik, sosial, budaya, ekonomi, dan politik bangsa.

Oleh karena itu, siswa kelas VA SDN 49 Kota Bengkulu yang belum tuntas perlu diadakan remedial. Menurut Daryanto (2014: 162) bahwa, remedial dapat diberikan kepada siswa yang belum mencapai kriteria ketuntasan belajar, kegiatan remedial bisa berupa menjawab pertanyaan, mengerjakan tugas atau membuat rangkuman dan waktu remedial bisa diatur berdasarkan kesepakatan antara guru dan murid juga remedial dapat dilaksanakan di luar jam efektif belajar.

Dilihat dari hasil perolehan data siswa kelas VA di Sekolah Dasar Negeri 49 Kota Bengkulu yang meliputi ketiga aspek yaitu (1) aspek kognitif; (2) kesadaran sejarah; (3) sikap nasionalisme; ada siswa yang mendapatkan nilai tinggi untuk kemampuan pada aspek kognitif sedangkan untuk kesadaran sejarah dan sikap nasionalismenya rendah, selain itu juga ada yang kemampuan kognitifnya rendah tetapi untuk kesadaran sejarah dan sikap nasionalismenya baik, ada juga siswa yang untuk ketiga aspek memiliki nilai cukup, dan yang terakhir ada siswa yang untuk ketiga aspeknya memiliki nilai yang sangat baik.

Untuk siswa yang mendapatkan nilai rendah pada aspek kognitifnya berarti bahan ajarnya yang perlu diperbaiki karena penggunaan bahasa pada bahan ajar sulit untuk dipahami oleh beberapa orang siswa. supaya untuk kedepannya bahan ajar yang digunakan dapat membuat siswa menjadi lebih mampu dalam memahami bahan ajar sejarah perjuangan rakyat Bengkulu. Sedangkan untuk sikap kesadaran sejarah dan sikap nasionalisme untuk siswa yang tingkat kesadaran sejarah dan nasionalismenya rendah perlu ditanamkan pada diri siswa pada setiap pembelajaran sejarah di kelas. 


\section{Kesimpulan}

Berdasarkan hasil penelitian dan pembahasan, maka dapat disimpulkan bahwa siswa Kelas V Sekolah Dasar Negeri 49 Kota Bengkulu mampu dengan rata-rata $68,11 \%$ dalam memahami bahan ajar muatan lokal sejarah perjuangan rakyat Bengkulu pada kecakapan akademik, sikap kesadaran sejarah dan nasionalisme. Namun bila dilihat dari ketuntasan belajar, siswa kelas V SDN 49 Kota Bengkulu dinyatakan belum tuntas, karena berdasarkan penilaian acuan patokan siswa dinyatakan tuntas apabila yang mendapatkan nilai 65 ke atas sebanyak 75-80\%. Rincian perolehan hasil penelitian pada aspek kecakapan akademik sebanyak 12 siswa $(52,17 \%)$ mampu memahami bahan ajar muatan lokal sejarah kerajaan Bengkulu, sebanyak 16 orang siswa $(69,56 \%)$ mampu memiliki sikap kesadaran sejarah dan sebanyak 19 orang siswa $(82,60 \%)$ mampu memiliki sikap nasionalisme.

\section{Saran}

Berdasarkan kesimpulan hasil penelitian, maka peneliti mengemukakan beberapa saran sebagai berikut:

1. Bagi siswa agar dapat menggunakan bahan ajar muatan lokal sejarah perjuangan rakyat Bengkulu untuk menambahkan pengetahuan dan menumbuhkan sikap kesadaran sejarah maupun sikap nasionalisme.

2. Materi dan kalimat yang ada dalam bahan ajar Sejarah Perjuangan Rakyat Bengkulu perlu disederhanakan lagi, karena siswa sulit menelaah beberapa kalimat yang tata bahasanya sulit dipahami mereka.

3. Untuk sikap kesadaran sejarah dan sikap nasionalisme siswa sudah baik, dan seharusnya dalam proses pembelajaran sejarah perlu ditanamkan sikap kesadaran sejarah dan sikap nasionalisme.

\section{Referensi}

Adjisoedarmo. 1991. Sejarah perlawanan terhadap imperalisme dan kolonialisme di daerah bengkulu. Jakarta : Departemen pendidikan dan Kebudayaan

Aman. 2011. Model Evaluasi Pembelajaran Sejarah. Yogyakarta: Penerbit Ombak.

Arikunto, Suharsimi. 2013. Dasar-Dasar Evaluasi Pendidikan. Jakarta: Bumi Aksara.

Arikunto, Suharsimi. 2010. Prosedur Penelitian Suatu Pendekatan Praktik Edisi (Revisi VI). Jakarta: Rineka Cipta.

Belawati, Tian, dkk. 2006. PengembanganBahan Ajar.Jakarta: Universitas Terbuka.

Daliman. 2012. Metode Penelitian Sejarah.Yogyakarta : Penerbit Ombak. 
Daryanto dan Dwicahyono, Aris. 2014. Pengembangan Perangkat Pembelajaran. Yogyakarta: Gava Media.

Fudyartanta. 2011. Psikologi Perkembangan. Yogyakarta : Pustaka Pelajar

Mulyasa. 2010. Kurikulum Tingkat SatuanPendidikan. Bandung: RemajaRosdakarya.

Prastowo, Andi. 2013. Pengembangan Bahan Ajar Tematik. Jogjakarta: DivaPress

Ranni. 1992. Perlawanan Terhadap Penjajahan dan Perjuanga

Menegakkan Kemerdekaan Indonesia di Bumi Bengkulu. Jakarta : Balai Pustaka

Sudaryono. 2013. Pengembangan Instrumen Penelitian Pendidikan. Yogyakarta: Graha Ilmu.

Susanto, Ahmad. 2013. Teori Belajar dan Pembelajaran di Sekolah Dasar. Jakarta: Fajar Interpramata.

Wardaya. 2009. Cakrawala Sejarah. Jakarta : Pusat Perbukuan Departemen Pendidikan Nasional

Wahyudhi, Madjid. 2014. Ilmu Sejarah Sebuah Pengantar. Jakarta : Prenada Media Group

Widoyoko, Eko Putro. 2011. Evaluasi Program Pembelajaran: Panduan Praktis bagi Pendidik dan Calon Pendidik. Yogyakarta: Pustaka Pelajar

Winarni, Endang Widi. 2012. Inovasi dalam Pembelajaran IPA. Bengkulu. Penerbitan FKIP UNIB.

Yaumi, Muhammad. 2014. Prinsip-Prinsip Desain Pembelajaran. Jakarta: Prenadamedia Group. 